\title{
PEMIKIRAN-PEMIKIRAN FONETIK IBNU JINNI (W. 392 H. / 1002 M.)
}

\author{
Arifuddin \\ arifarifin81@gmail.com \\ Jurusan Sastra Arab Fakultas Sastra dan Seni Rupa UNS \\ dan Pusat Studi Ekonomi Islam LPPM UNS
}

\begin{abstract}
This article discusses phonetic thoughts of Ibnu Jinni, scientist who became a central figure in the development of Arabic phonetics. His work named Sirru Shinâ'atilI'râb is the first phonetic book in Arabic. He also called this science with terminology 'Ilmul-Ashwât which is still used by Arabic scientist until now. These features are behind the writing of this article. This article to describe Ibnu Jinni curriculum vitae, the book Sirru Shinâ'atil-I'râb, and phonetic thoughts of Ibnu Jinni and his contribution in Arabic phonetic progress The conclusion is that Ibnu Jinni has given big contribution in Arabic phonetic progress. The most important thing is his research about vowel. There are so many vowel studied and be the main reference for the next study.
\end{abstract}

Keywords: Arabic phonetic, Ibnu Jinni, Sirru Shinâ'atil-I'râb

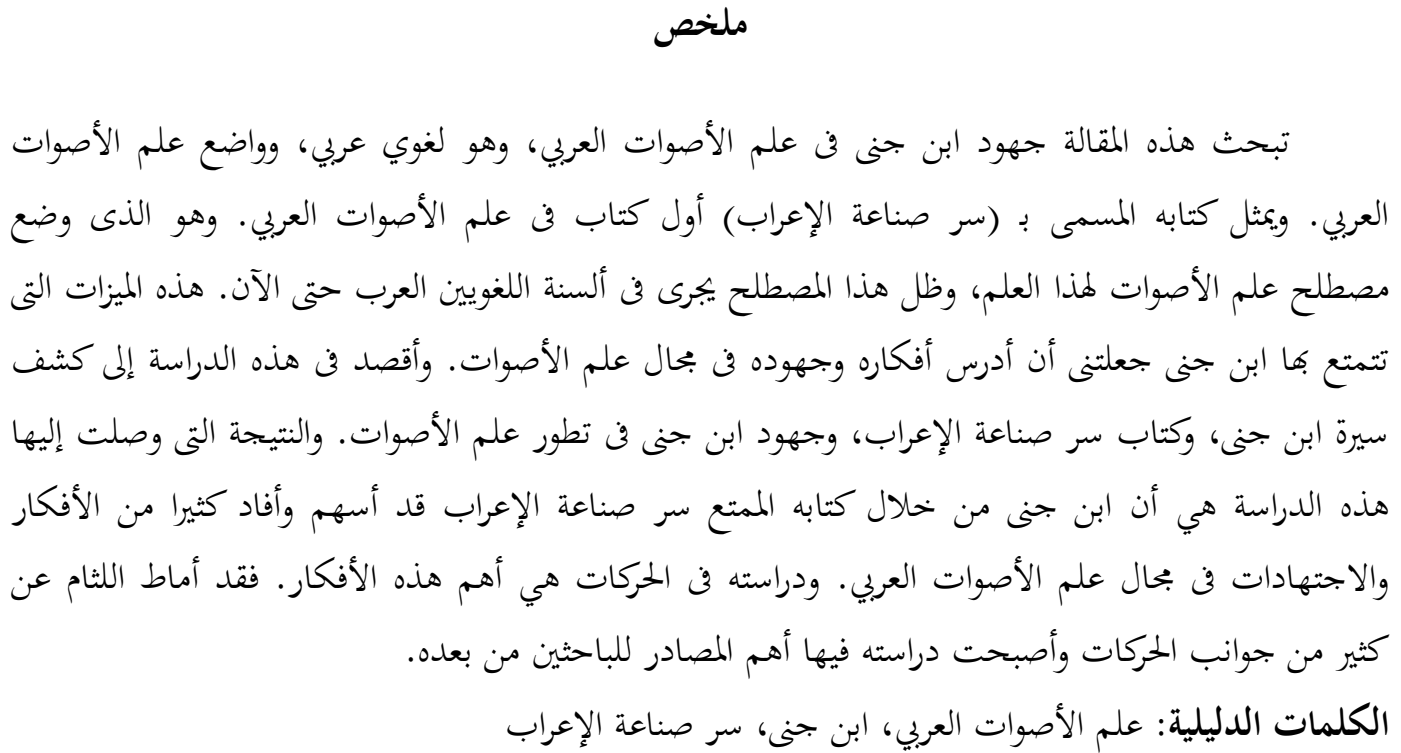

\section{Pendahuluan}

Fonetik

mempelajari mempertimbangkan arti. Bagaimana bunyi bahasa itu diciptakan oleh alat ucap dan macam-macam bunyi. Ilmu ini menjadi penting dalam ranah ilmu linguistik karena mengkaji unsur terkecil dari bahasa yaitu bunyi bahasa.

Dalam sejarah perkembangan ilmu bahasa, bangsa Timur yang diwakili oleh
India dan Arab dipandang memiliki khazanah kajian bahasa yang cukup tua, terutama dalam bidang fonetik. Kedua bangsa tersebut adalah pioner kajian fonetik dan inspirator bagi bangsa-bangsa yang lain. Keunggulan ini dikarenakan adanya kitab suci yang dipercaya oleh kedua bangsa tersebut, yaitu Weda dan Alquran.

Sejak Alquran diturunkan dan agama Islam dianut oleh sebagian besar 
bangsa Arab, perkembangan ilmu bahasa berkembang pesat. Banyak disiplin ilmu bahasa lahir dari rahim Alquran. Lahirnya kajian fonetik Arab pada awalnya adalah bagian dari kajian Alquran. Bagaimana Alquran dilafalkan dengan benar sesuai kaidah bunyi bahasa Arab.

Fonetik Arab banyak dikaji oleh para ahli bahasa seperti Imam Khalil dan Sibawaih. Pada awalnya, mereka belum mengkaji fonetik secara mandiri. Pembahasan fonetik masih bercampur dengan bidang ilmu yang lain. Sampai akhirnya datang Ibnu Jinni yang menjadikan fonetik sebagai disiplin ilmu tersendiri dan menamainya 'ilmu 'l-ashwāt dalam bukunya Sirru Shināti 'l-I'rāb.

Artikel ini akan mengkaji pendapatpendapat fonetik Ibnu Jinni yang telah menjadi tokoh sentral ilmu fonetik Arab melalui penelusuran data-data dalam beberapa literatur ilmu bahasa Arab. Sitematika penulisan artikel ini terbagi menjadi tiga bagian. Pertama adalah tentang Ibnu Jinni, kedua tentang Sirru Shināti 'l-I'rāb, dan ketiga tentang pendapat-pendapat fonetik Ibnu Jinni.

\section{Ibnu Jinni}

Nama lengkapnya adalah Usman bin Jinni. Muhammad Ali An-Najjar, dalam pengantar al-Khashäish (Jinni, 2000, juz 1: 5), menyebutkan bahwa orang tua Ibnu Jinni berkebangsaan Romawi dan menjadi budak Sulaiman bin Fahd bin Ahmad dari kabilah Azed. Keberadaan Ibnu Jinni yang tidak memiliki garis keturunan bangsa Arab menjadi jawaban logis mengapa dalam literatur biografi nasab Ibnu Jinni berhenti sampai ayahnya saja. Hanya para ulama yang bergaris keturunan Arab terjaga silsilah keturunannya. Sebab, bagi mereka garis keturunan adalah identitas pribadi yang harus terjaga dari generasi ke generasi. Sedangkan ulama yang bergaris keturunan non-Arab, garis keturunan itu tidak dapat dilacak lebih jauh. Kenyataan ini bisa kita temukan saat meneliti nasab ulama-ulama non Arab, kebanyakan nasabnya tidak terjaga sebagaimana orang Arab.

Ibnu Jinni dilahirkan di kota Mosul, Irak utara. Para sejarawan tidak menemukan catatan yang pasti terkait tahun berapa Ibnu Jinni dilahirkan. Pendapat yang meraka sampaikan bersifat spekulatif. Mereka menulis Ibnu Jinni dilahirkan sebelum tahun $330 \mathrm{H}$. Imam Abul Fida' menulis tahun kelahiran Ibnu Jinni adalah tahun $302 \mathrm{H}$. Sejarawan Ibnu Qadli Syuhbah menyatakan usia Ibnu Jinni saat meninggal 70 tahun. Jika dihitung dari tahun wafatnya, yaitu tahun $392 \mathrm{H}$., maka tahun kelahirannya adalah $322 \mathrm{H}$ atau 321 H. (Jinni, 2000, juz 1: 9)

Riwayat pendidikan Ibnu Jinni bermula di tanah kelahirannya, Mosul. Di sana, dia belajar ilmu nahwu kepada Ahmad bin Muhammad al-Maushiliy asySyāfi'iy yang dikenal dengan sebutan alAkhfasy. Saat itu, ilmu nahwu di kota Mosul sudah berkembang pesat. Ilmu ini dibawa pertama kali oleh Maslamah bin Abdullah al-Fihriy. Banyak ulama ilmu nahwu yang lahir dari kota ini. (Jinni, 2000, juz 1: 11)

Selain ilmu nahwu, Ibnu Jinni juga belajar sastra kepada Imam Abu Ali alFārisiy. Informasi ini dikemukakan oleh Ibnu Khallikan. Dia menulis (Khallikan, 1994, juz 3: 246): "Dia belajar sastra kepada Abu Ali al-Fārisiy, kemudian mengajar di kota Mosul. Suatu saat, gurunya Abu Ali berkunjung kepadanya dan melihatnya sedang mengajar banyak murid-murid. Abu Ali berkata: "Kamu belum pantas, kamu masih bodoh". Dia langsung meninggalkan majlisnya, dan berguru kepada Abu Ali hingga menjadi mahir".

Dari data di atas, an-Najjar menyimpulkan bahwa Ibnu Jinni berguru kepada Abu Ali pada masa kecil. Hanya saja, data di atas tidak menjelaskan nama daerah dimana Ibnu Jinni berguru. Abu Ali masuk ke kota Baghdad pada tahun $307 \mathrm{H}$ diduga kuat, kota Baghdad adalah nama daerah tersebut, jika benar informasi yang 
dikemukakan oleh Ibnu Khallikan. (Jinni, 2000, juz 1: 11)

Hubungan guru-murid antara $\mathrm{Abu}$ Ali dan Ibnu Jinni sangatlah kuat. Ibnu Jinni selalu menunjukkan dalam karyakaryanya bahwa dia adalah murid yang taat kepada gurunya itu dan mengakui jasa-jasa besarnya.

Para sejarawan, kecuali Ibnu Khallikan, hampir sepakat bahwa Ibnu Jinni pertama kali mengenal Abu Ali alFārisiy saat dia mengajar para muridmuridnya di masjid kota Mosul. Dalam riwayat Ibnu 'l-Anbāriy diceritakan (AlAnbāriy, 1985: 245) bahwa Abu Ali suatu hari berkunjung ke kota Mosul dan masuk ke masjid jami' kota Mosul. Ibnu Jinni, yang saat itu masih muda, sedang mengajarkan ilmu nahwu kepada muridmuridnya. Materi yang diajarkan adalah tentang mengganti huruf waw dengan alif. Abu Ali kemudian membantah pendapat Ibnu Jinni, dan Ibnu Jinni tidak dapat menjawab bantahan tersebut. Abu Ali berkata: "Kamu sudah berani mengajar, padahal kamu masih perlu belajar lagi". Abu Ali kemudian berdiri dan meninggalkan tempat. Saat itu, Ibnu Jinni belum mengenal Abu Ali, dia bertanya kepada seseorang, dan diberitahu kalau orang itu adalah Abu Ali. Segera dia mencarinya, dan dia menjumpainya di kota Sumeria dalam perjalanan ke kota Baghdad. Sejak saat itu, dia selalu ikut dan berguru kepada Abu Ali.

Dalam riwayat di atas, jelas sekali bahwa Ibnu Jinni belum mengenal Abu Ali. Riwayat inilah yang diyakini oleh banyak sejarawan Arab.

Kunjungan Abu Ali ke kota Mosul terjadi pada tahun $337 \mathrm{H}$. Abu Ali memang orang yang suka mengembara ke berbagai negeri. Sejak tahun tersebut Ibnu Jinni selalu ikut dalam perjalanan dan persinggahan $\mathrm{Abu}$ Ali dan berguru kepadanya. (Jinni, 2000, juz 1: 18)

Sebagian besar karya-karya Ibnu Jinni ditulis saat Imam Abu Ali masih hidup. Karya-karya itu mendapatkan pengakuan dan penghargaan dari sang guru. Ibnu Jinni juga sering mengutip dan memuji pendapat gurunya. Dalam karyanya, al-Khashāish, (1/208) dia mengatakan: "Suatu hari saya mengatakan kepada Abu Bakar Ahmad bin Ali arRāziy, saat itu kami banyak memperbincangkan kecerdasan $\mathrm{Abu}$ Ali dan reputasinya yang tinggi: "Saya menduga masalah ini sudah diketahui olehnya. Dan dia telah berjasa memberikan sepertiga argumentasi ilmu nahwu ini kepada para ulama". Tampak Ahmad bin Ali ar-Rāziy begitu menyimak perkataan tersebut, dan menyetujuinya". Di tempat yang lain (1/276), Ibnu Jinni mengatakan: "Māsyā'a 'l-Lāh, semoga Allah selalu merahmatinya. Tampak sekali betapa kuat argumentasinya, dan betapa tinggi pengetahuannya tentang ilmu bahasa Arab ini. Seakan-akan dia tercipta untuknya. Bagaimana tidak?! Dia telah berbakti bersama para tokoh-tokoh terkemuka ilmu bahasa selama 70 puluh tahun merumuskan argumentas-argumentasi ilmu bahasa dan memecahkan problematikanya. Dia juga menjadikan ilmu bahasa sebagai perhatian utamanya, dan tidak tergoda oleh kesenangan dunia".

Hubungan guru murid antara $\mathrm{Abu}$ Ali dan Ibnu Jinni ini seperti hubungan Imam Khalil dan muridnya, Imam Sibawaih, dimana sang murid banyak mengutip ilmu sang guru dan menuliskannya dalam karya-karyanya. Hanya saja, dalam konteks Ibnu Jinni sang guru terkadang bertanya dan meminta pendapat muridnya, bahkan keduanya berdiskusi panjang. Hal ini seperti yang diceritakan Ibnu Jinni dalam al-Khashāish (1/387), suatu hari saya masuk kepada Abu Ali di sore hari. Dia bertanya kepadaku: "Dimana kamu? Saya mencarimu". "Ada apa, guru?". "Apa pendapatmu tentang kata (حَوْرِيتَ)?". Kami pun berdiskusi bersama dan belum mendapatkan jawabannya. Abu Ali berkata: "(Kata) itu adalah dialek Yaman, berseberangan dengan dialek Bani Nizar."

Meskipun begitu dekat dan taat kepada gurunya, Ibnu Jinni tidak fanatik 
kepada sang guru. Dalam beberapa permasalahan, dia tidak sependapat dengan gurunya. Seperti dalam kata (تِحْفَاف), apakah huruf ta' itu imbuhan untuk disamakan dengan wazan (قِّرَكَاس)? Abu Ali berpendapat iya dan memberikan argumentasinya. Ibnu Jinni kemudian berkomentar: "Menurut saya pendapat itu jauh dari kebenaran", dan dia pun mengajukan argumentasinya. (Jinni, 2000, juz 1: 231)

Selain Abu Ali al-Fārisiy, ulama yang Ibnu Jinni pernah berguru kepadanya adalah Ibnu Miqsam Abu Bakar Muhammad bin al-Hasan, seorang ahli ilmu qira'at, Abu al-Faraj al-Ashfihāniy, penulis ensiklopedi sastra al-Aghāniy, Abu Bakar Muhammad bin Harun ar-Rauyāniy, murid Abu Hatim as-Sijistaniy, dan Muhammad bin Salamah, murid alMubarrid. Ibnu Jinni juga meriwayatkan bahasa dari orang Arab Baduwi yang masih fasih. Diantaranya adalah $\mathrm{Abu}$ Abdillah Muhammad bin al-'Assaf al'Uqailiy at-Tamīmiy. Ibnu Jinni menyebutnya dengan Abu Abdillah asySyajariy. (Jinni, 2000, juz 1: 15)

Ibnu Jinni juga memiliki hubungan yang erat dengan al-Mutanabbi, penyair Arab klasik terkenal. Keduanya sering bertemu dan berdiskusi di majlis ilmu Raja Saifuddaulah bin Hamdan di Aleppo, dan majlis ilmu Raja 'Adlduddaulah di Syiraz. Al-Mutanabbi sangat menaruh hormat dan memuji Ibnu Jinni. Dia mengatakan: "Dia adalah sosok ulama yang kedudukannya tidak banyak orang mengetahuinya". Jika ditanya tentang permasalahan ilmu nahwu yang pelik dalam syair-syairnya, alMutanabbi mengatakan: "Tanyakan itu kepada saudaraku, Abu al-Fath (Ibnu Jinni)." Dia juga berkata: "Datanglah kepada Syeikh Ibnu Jinni dan tanyakan masalahmu itu kepadanya. Dia akan menjawab, baik seperti yang saya inginkan atau tidak". Pernyataan al-Mutanabbi ini menunjukkan penghormatannya atas kedalaman ilmu dan keragaman mazhab bahasa yang dianut oleh Ibnu Jinni. (Jinni, 2000, juz 1: 21)

Sebaliknya, Ibnu Jinni juga sering melayangkan pujian kepada al-Mutanabbi di beberapa tulisannya. Dia menyebutnya dengan sebutan "penyair kami”. Dalam alKhashāish (juz 1: 239) dia menulis: "Penyair kami, al-Mutanabbi menceritakan kepada saya, dan dia adalah orang yang jujur ..." Bukti lain atas kecintaan dan penghormatan Ibnu Jinni kepada alMutanabbi adalah tulisan Imam Yaqut alHamawiy yang menjelaskan bahwa Ibnu Jinni suka menanyakan kabar alMutanabbi kepada Ali bin Hamzah alBashriy. Karena, setiap kali ke kota Baghdad al-Mutanabbi menginap di rumahnya. (Jinni, 2000, juz 1: 23)

Kepakaran Ibnu Jinni dalam bidang ilmu bahasa sudah diakui oleh banyak ahli dan tidak ada yang meragukannya, baik dari segi periwayatan maupun penguasaan materi. Dalam hal periwayatan bahasa ini, Ibnu Jinni adalah referensi terpercaya di mata para pakar bahasa. Selain karena kompetensi, silsilah periwayatan yang dimiliki Ibnu Jinni sangat terpercaya. Dia banyak meriwayatkan bahasa dari orang Arab Baduwi yang masih diakui kemurnian bahasanya. Diantaranya yang paling menonjol adalah Abu Abdillah Muhammad bin al-'Assaf. Sedangkan dalam penguasaan materi ilmu bahasa, karya-karya Ibnu Jinni banyak dirujuk oleh para pakar setelahnya.

Pendapat-pendapat linguistik Ibnu Jinni banyak dipersoalkan oleh para sejarawan tentang afiliasi aliran pemikiran linguistiknya, apakah menginduk ke aliran pemikiran kota Basrah, kota Kufah, ataukah Baghdad? Sebagian ulama berpendapat Ibnu Jinni berafiliasi ke aliran Basrah, sebagian yang lain berpendapat beraliran Baghdad, dan sebagian yang lain berpendapat beraliran Kufah. Bahkan, ada pula yang berpendapat beraliran independen.

Studi terkait mazhab Ibnu Jinni telah dilakukan oleh akademisi Irak, Fadhil Shaleh as-Samirrā'i. Dia berpendapat, Ibnu 
Jinni beraliran mazhab Basrah. Untuk memperkuat pendapatnya ini dia menggunakan empat pendekatan, yaitu (1) dasar-dasar teori mazhab Basrah dan sejauh mana Ibnu Jinni mengimplementasikannya, (2) terminologi tata bahasa Ibnu Jinni, (3) di mazhab manakah Ibnu Jinni menempatkan pendapat-pendapatnya, (4) contoh-contoh pendapat Ibnu Jinni tentang beberapa masalah kontroversial tata bahasa. (asSamirrāi, 1969: 255)

Pada pendekatan pertama asSamirrāi menjelaskan bahwa prinsip utama teori mazhab Basrah adalah (1) meriwayatkan bahasa dari orang-orang Arab Baduwi yang masih fasih dan diakui secara luas. as-Samirrāi (1969: 261) menyatakan, Ibnu Jinni berpegang teguh kepada mazhab Basrah, karena dia tidak mudah menerima riwayat bahasa dari satu orang kecuali jika memenuhi syarat-syarat tertentu.

Dalam pendekatan kedua asSamirrāi juga menegaskan (1969: 265) bahwa Ibnu Jinni banyak menggunakan terminologi tata bahasa mazhab Basrah seperti ismul-fâ'il, jar, dlamîr, al-'athfu, al-badal.

Sedangkan dalam pendekatan ketiga as-Samirrāi (268-269) menyatakan, dalam banyak pernyataannya Ibnu Jinni mengafiliasikan dirinya kepada mazhab Basrah. Seperti dalam al-Khashāis dia menyatakan, ulama kami tidak membenarkan adanya kata (قَنَيْنُ), meskipun ulama Baghdad telah meriwayatkan kata tersebut. Dan yang dimaksud dengan ulama kami adalah ulama mazhab Basrah. Dalam permasalahan (Jَ), Ibnu Jinni menyatakan: "Demikian juga lam pada kata (لَعَلَ), menurut kami huruf tersebut adalah tambahan. Tidakkah engkau mengetahui, orang Arab kadangkala menghilangkan huruf tersebut (عَلَّ)". Maksud dari pernyataan "kami" di atas adalah ulama Basrah karena pendapat ini adalah pendapat mereka.

As-Samirrāi (276-290) juga memperkuat kesimpulannya itu dengan memberikan data-data pendapat Ibnu Jinni yang mengikuti pendapat ulama Basrah dalam permasalahan kontroversial tata bahasa Arab. Sebanyak 55 permasalahan kontroversial tata bahasa, seperti yang dicatatkan as-Samirrāi, Ibnu Jinni memilih pendapat ulama Basrah di dalamnya.

Pendapat ini juga didukung oleh akademisi Irak Husam Sa'id an-Nu'aimi. Dia (1990: 40) mengatakan: "Mazhab ilmu nahwu di buku-buku Ibnu Jinni adalah mazhab Basrah, dan dia juga seorang mujtahid tata bahasa yang juga memiliki pedapatnya sendiri”.

Pendapat lain mengatakan Ibnu Jinni bermazhab Baghdad. Mazhab yang muncul pada abad keempat Hijriyyah ini menciptakan metodologi baru dalam penelitian ilmu tata bahasa Arab, yaitu seleksi dan kompromisasi pendapat ulama Basrah dan Kufah. Dalam al-Madārisu ' $n$ Nachwiyyah, Syauqi Dlaif, mencatat sebuah kesimpulan, meskipun pendapatpendapat Ibnu Jinni kental dengan cita rasa ulama Basrah, dia beserta gurunya, Abu Ali al-Fārisi tidak dapat dikatakan bermazhab Basrah. Sebab, kecenderungan menggunakan metode baru ala mazhab Baghdad masih mewarnai paradigma Ibnu Jinni. Adapun penggunaan terminologi alBaghdādiyyūn dengan bermaksud ulama Kufah, seperti yang banyak dikemukakan oleh as-Samirrāi sebagai pembuktian untuk pendapatnya, dikarenakan para tokoh mazhab Baghdad pada masa-masa pendiriannya banyak didominasi ulama Kufah seperti Ibnu Kaisan (299 H), Ibnu Syuqair $(315 \mathrm{H})$, dan Ibnu al-Khayyāth (320 H). (Dlaif, 1992: 246).

Tampaknya, pendapat ini lebih realistis, bahwa Ibnu Jinni beraliran mazhab Baghdad meski tidak sedikit pendapat-pendapatnya yang cenderung ke mazhab Basrah. Hal ini disebabkan, pemikiran tata bahasa pada masa Ibnu Jinni tidak lagi menggunakan metode 
mazhab Basrah dan Kufah secara murni, melainkan sudah ada metode baru yaitu seleksi dan kompromisasi antara mazhab Basrah dan Kufah.

Dalam banyak referensi dikatakan Ibnu Jinni adalah ahli ilmu nahwu (annallwiyyu). Terminologi an-nahwiyyu dalam referensi klasik bermakna umum, yakni mencakup ilmu sharaf (morfologi) dan ilmu nahwu (sintaksis). Dari dua bidang ilmu tata bahasa ini, diyakini Ibnu Jinni lebih kompeten dalam bidang ilmu sharaf. Hal ini dikarenakan kelemahan Ibnu Jinni saat masih belia, seperti dalam kisah perkenalannya dengan Abu Ali alFarisi, tampak pada ilmu sharaf sehingga beliau termotivasi dengan kuat untuk expert di bidang itu. Kisah lain yang menguatkan keyakinan di atas adalah kisah Ibnu Jinni bersama ar-Raba'i saat keduanya melihat seekor anjing dan arRaba'i meminta Ibnu Jinni untuk mengusirnya lalu Ibnu Jinni tidak berani. Ar-Raba'i berkata: "Ibnu Jinni! Kamu ini takut dengan anjing, seperti engkau takut dengan ilmu nahwu". Terdapat juga pendapat-pendapat Ibnu Jinni dalam bidang ilmu nahwu yang tidak sejalan dengan pendapat mayoritas ahli, diantaranya adalah boleh membaca ( مررت (بزيدٍ وعمراً dengan membaca nashab kata (عمراً) karena di'athafkan kepada kedudukan asal kata (بزيد) yang berkedudukan maf'ul bih. (Jinni, 2000, juz 1: 48)

Riwayat ini menurut hemat penulis tidak serta merta menodai atau meragukan kompetensi Ibnu Jinni dalam bidang ilmu tata bahasa. Sudah menjadi hal yang lumrah seorang ulama klasik, yang dikenal dengan pakar ilmu multidisipliner, memiliki kelemahan di satu bidang keilmuan. Pada konteks Ibnu Jinni, kelemahan yang disandangnya dalam bidang ilmu nahwu tidak menjadikan kemahiran berbahasa yang dimiliki menjadi rusak.
Kepakaran Ibnu Jinni dalam bidang ilmu bahasa dapat dibuktikan dengan karya-karya beliau yang mencapai 49 buku. (Jinni, 2000, juz 1: 61-68) Diantaranya yang paling terkenal adalah al-Khashāish, Sirru Shinā'atil-I'rāb, dan al-Munshif fí Syarchi Tashrîfi 'l-Mâziniy.

Ibnu Jinni meninggal dunia di kota Baghdad pada Kamis malam Jumat, 27 Shafar 392 H / 1002 M. (Jinni, 2000, juz 1: 59)

\section{Sirru Shinā'atil-I'rāb}

Ahmad Mukhtar Umar (1988:100) menyatakan bahwa ulama bahasa Arab yang pertama kali menulis fonologi secara khusus dalam satu karya adalah Abul Fath Usman Ibnu Jinni dalam bukunya Sirru Shinā'atil-I'rāb.

Sebelum muncul buku ini, fonologi dibahas oleh para ahli bahasa Arab bercampur dengan pembahasan ilmu-ilmu yang lain. Ahli ilmu nahwu, seperti Imam Sibawaih, az-Zajjaj, dan az-Zamakhsyari mengkaji permasalahan fonologi dalam karya-karya ilmu nahwu sebagai pengantar untuk pembahasan bab idghām, i'lāl, dan ibdāl. Demikian juga dengan ahli leksikologi, seperti Imam Khalil, dan Ibnu Duraid, pembahasan fonologi ditempatkan di mukaddimah kamus masing-masing. Ahli ilmu tajwid juga melakukan hal yang sama, terutama terkait pembahasan titik artikulasi bunyi. Para ahli ilmu Alquran juga membahas sebagian permasalahan fonologi di bab Keharmonisan Bunyi dalam Alquran. Juga para penulis ensiklopedi sastra, seperti al-Jahiz dalam al-Bayân wat-Tabyîn, mencatat beberapa hasil penelitian para peneliti Arab terkait bunyi bahasa. (Umar, 1988: 94-99).

Penelitian fonologi Arab pada masa Ibnu Jinni sudah bisa dibilang maju dan bernilai tinggi. Beberapa capaian penelitian ini diantaranya adalah (Umar, 1988: 114-117):

1. Sistem alfabet bahasa Arab yang didasarkan atas titik artikulasi, mulai dari yang paling dalam 
sampai dengan yang paling luar yaitu bibir. Sistem ini pertama kali dikenalkan oleh Imam Khali dalam kamusnya, al-'Ain. Kemudian direvisi oleh muridnya, Imam Sibawaih.

2. Nama-nama alat ucap dan titik artikulasi bunyi. Imam Khalil menyebut delapan titik artikulasi, sedangkan Imam Sibawaih dan Ibnu Duraid menyebut enam belas titik artikulasi.

3. Cara artikulai bunyi, bunyi plosif, frikatif, antara plosif dan frikatif, dan afrikatif.

4. Identifikasi bunyi velarisasi

Capaian ini yang membuat seorang ahli bahasa berkebangsaan Jerman, Bergestraiser berkomentar bahwa dalam ilmu fonologi bangsa Eropa kalah start dengan bangsa Timur, yaitu bangsa India dan Arab. Komentar yang sama juga dikemukakan ahli bahasa berkebangsaan Inggris, Ferth. Dia mengatakan, ilmu fonologi telah muncul dan berkembang pesat berkat jasa dua bahasa kitab suci, yaitu bahasa Sansekerta dan bahasa Arab. (Umar, 1988: 114).

Dengan munculnya buku Sirru Shinā'atil-I'rāb, fonologi Arab telah terbentuk dalam satu disiplin ilmu bahasa tersendiri. Buku ini didedikasikan secara khusus oleh penulisnya untuk meneliti segala hal yang terkait dengan bunyi bahasa Arab. Materi pembahasannya mencakup (Umar, 1988: 100):

1. Kumpulan aksara bahasa Arab, urut-urutannya, dan titik artikulasi masing-masing.

2. Karakter umum masing-masing bunyi, dan macam-macamnya dari berbagai sudut pandang.

3. Perubahan bunyi dalam struktur kata.

Dalam mukaddimah Sirru Shinā'atil-I'rāab, Ibnu Jinni menegaskan (1993: 3): "Buku ini membahas seluruh aturan-aturan dalam bunyi bahasa Arab, karakter masing-masing, dan kedudukannya dalam ujaran. Saya berupaya menelitinya secara komprehensif dan mendalam serta membuktikannya". Di halaman berikutnya Ibnu Jinni juga menyatakan (1993: 4): "Saya menjelaskan keadaan bunyi bahasa saat berada di titik artikulasi dan alur bunyi, macam-macam bunyi: bersuara dan tidak bersuara, plosif dan frikatif, bunyi konsonan dan vokal, bunyi velar dan yang tidak, huruf yang berharakat dan bersukun...".

Sedangkan metode yang digunakan dalam Sirru Shinā'atil-I'rāb adalah menggunakan sistem urutan abjad Arab. Urutan abjad Arab pada masa Ibnu Jinni memiliki dua sistem, pertama berdasarkan titik artikulasi (dari yang paling dalam sampai yang paling luar) dan kedua sistem أ، ب، (

… Ibnu Jinni menggunakan sistem kedua yang pada masanya banyak digunakan. Dia menyusun bab-bab dalam bukunya itu sesuai urutan abjad yang berlaku sampai sekarang. Dalam setiap bab Ibnu Jinni mengawalinya dengan menjelaskan sifat bunyi; bersuara atau tidak, menjelaskan penggunaan bunyi tersebut dalam kata, baik sebagai bunyi asal, bunyi hasil perubahan, atau bunyi tambahan. Kemudian memberikan beberapa contoh untuk masing-masing penggunaan bunyi tersebut, baik dalam posisi di awal kata, tengah kata, dan akhir kata. (Hasan Hindawi dalam Jinni, 1993: 33)

Ada beberapa akademisi yang memandang bahwa pembahasan utama buku Sirru Shinā'atil-I'rāb adalah morfofonemik. Seperti yang dinyatakan oleh Hasan Hindawi dalam kajian pengantar Sirru Shinā'atil-I'rāb (Jinni, 1993: 18-19), bahwa pembahasan utama buku ini adalah mengkaji perubahan bunyi bahasa Arab (الدراسة التصريفية لحروف المعجم), yang dalam istilah ilmu linguistik modern adalah kajian morfofonemik. Sedangkan pembahasan fonologi oleh Ibnu Jinni 
ditempatkan sebagai dasar pembahasan utama karena Ibnu Jinni menyadari perubahan-perubahan yang terjadi pada bunyi hanya dapat dijelaskan setelah memahami hal ihwal bunyi bahasa Arab secara sempurna.

Pendapat ini menurut penulis tidak serta merta menggugurkan kebenaran pernyataan Ahmad Mukhtar Umar di atas, bahwa disiplin ilmu fonologi Arab pertama kali dimunculkan secara independen oleh Ibnu Jinni. Karena, buku ini adalah satusatunya buku yang pada masanya diperuntukkan untuk mengkaji bunyi bahasa Arab secara independen, tidak seperti buku-buku yang lain yang mengkaji fonologi bercampur dengan pembahasan disiplin ilmu yang lain. Hal inilah yang menjadi tujuan pembahasan utama Ibnu Jinni. Dan seperti yang dikatakan dalam mukaddimahnya, Ibnu Jinni mengembangkan pembahasan bunyi itu secara luas sehingga mencakup perubahan bunyi dalam kata.

\section{Pemikiran Fonetik Ibnu Jinni}

Pemikiran fonetik Ibnu Jinni hadir di tengah sejumlah pemikiran fonetik para linguis Arab terkenal seperti Khalil bin Ahmad, Sibawaih, Ibnu Duraid, dan Abu Ali al-Fārisi. Pemikiran-pemikiran itu telah berkembang pesat. Diyakini, Ibnu Jinni telah mempelajari dan memanfaatkan pemikiran-pemikiran tersebut secara langsung dari sumber-sumbernya melalui jalur riwayat dari para guru-guru.

Para ahli bahasa secara detil telah mengkaji bunyi bahasa Arab, titik artikulasi, dan sifat masing-masing bunyi. Mereka juga telah mengkaji perubahanperubahan fonem seperti idghām, ibdāl, dan i'lāl. Hanya saja, mereka seringkali tidak konsisten dalam mengkaji kaidahkaidah fonetik, terkadang mereka hanya mendeskripsikan saja tanpa didukung argumentasi nyata. (An-Nu'aimi, 1980: 7273)

Ibnu Jinni menuangkan pemikiranpemikiran fonetik tidak hanya dalam Sirru Shinā'atil-I'rāab, melainkan juga dalam karya-karya yang lain, utamanya alKhashäish. Pemikiran-pemikiran tersebut menunjukkan tingkat kepakaran Ibnu Jinni dalam hal linguistik, khususnya fonetik yang diakui oleh para linguis Arab modern. Beberapa pemikiran Ibni Jinni terkait fonetik adalah sebagai berikut:

\section{Teori Asal Muasal Bunyi}

Terdapat perbedaan sikap diantara para linguis dalam menanggapi isu bagaimana awal mulanya lahirnya bahasa manusia. Ada yang memandang, mendiskusikan isu ini tidak ada untungnya bagi ilmu pengetahuan, bahkan melanggar kode etik ilmu pengetahuan itu sendiri karena tidak adanya data empiris yang wajib ada dalam setiap penelitian ilmiah. Selain itu, sebagian memandang isu itu sudah masuk ranah metafisika. Shubhi Shalih dalam Dirāsātu Fiqhil-Lughati menegaskan (2004: 35): "Sudah seharusnya kajian bahasa direvitalisasi dengan menjauhkan persoalan awal mula bahasa manusia yang penuh dengan ketidakjelasan dan gaib".

Di sisi lain, sejumlah ilmuwan memandang, membicarakan isu ini tetap menarik dan mendatangkan manfaat ilmiah. Paling tidak, tidak membiarkan isu tersebut terkubur dalam kemisteriusan. Inilah yang mendorong Ibnu Jinni untuk membicarakan isu awal mula bahasa manusia, apakah datang sebagai ilham dari Tuhan, ataukah hasil olah pikir dan konsensus sekelompok manusia? Ibnu Jinni memilih opsi yang kedua yang mengatakan bahasa adalah hasil konsensus manusia. Hal ini menurutnya, karena tidak ada teks agama (riwayat hadis) yang sahih yang memperkuat opsi pertama. Semua riwayat hadis yang menafsirkan bahwa Allah telah mengajarkan kepada Nabi Adam sejumlah nama-nama (QS. 2:31) bagi Ibnu Jinni tidak menginformasikan secara pasti tentang kemunculan bahasa. Selain itu, riwayat-riwayat tersebut mengandung pertentangan substansi. (anNu'aimi, 1980: 271) 
Dalam hal ini, yang menarik dalam pembahasan Ibnu Jinni adalah dia mengajukan teori fonetik terkait lahirnya bahasa manusia. Dalam al-Khashāish, (2000: 1/46-47) Ibnu Jinni menuliskan: "Sejumlah ulama berpandangan awal mula bentuk bahasa manusia adalah suara-suara alam yang sering didengar seperti desir angin, gemericik air, suara keledai, gagak, dan sejenisnya. Kemudian terlahirlah setelah itu bahasa-bahasa manusia. Pendapat ini, menurutku, adalah pendapat yang bisa diterima".

Perlu digarisbawahi bahwa pendapat di atas bukan pendapat Ibnu Jinni, melainkan kutipan dari pendapat sejumlah ahli bahasa yang dipilih olehnya. Tentang siapa sejumlah ahli bahasa yang dimaksud Ibnu Jinni, menurut an-Nu'aimi (1980: 272) tidak ada data valid yang menunjukkan hal tersebut.

Teori yang dipilih Ibnu Jinni di atas dapat dipahami bahwa pada mulanya manusia berbicara dengan meniru suarasuara alam. Saat itulah manusia sadar akan kemampuannya menggunakan alat ucap. Kemudian manusia merasa nyaman saat mampu menyatakan apa yang ada dalam pikirannya kepada orang lain, meskipun menggunakan bahasa yang masih sangat primitif. Kemudian tiba masa, yang tidak diketahui pasti berapa lama, dimana manusia berusaha mengembangkan kemampuan berbicaranya untuk mengungkapkan kebutuhan sehari-hari dan mulai meninggalkan bentuk suara-suara alam tersebut. Kemampuan berbicara itu semakin berkembang menyesuaikan kebutuhan hidup dan perkembangan akal pikiran manusia, dan bahasa manusia tumbuh secara bertahap. (an-Nu'aimi, 1980: 273)

\section{Bunyi Bahasa Arab}

\section{a. Titik Artikulasi}

Ibnu Jinni dalam mengkaji titik artikulasi lebih condong kepada pendapat Imam Siwabaih yang membagi titik artikulasi ke dalam enam belas bagian. Dalam bukunya, Sirru
Shinā'atil-I'rāb (1993:46) beliau menyebutkan keenam belas titik artikulasi tersebut.

(1) Pangkal bawah rongga tekak titik artikulasi bunyi [^], ['], dan [-ه]. Ibnu Jinni mengatakan, urutan yang tepat adalah $[\varsigma],[']$, dan $[-\infty]$, yakni titik artikulasi ['] sebelum [-ه]. Tidak seperti pendapat alAkhfasy yang menjadikan ['] satu tempat dengan [-ه]. Ibnu Jinni berargumen bahwa jika ['] diberi harakat maka artikulasi bunyi ini tertekan ke bawah dan berubah menjadi [^], bukan [-ه] (1993:45). Hasil penelitian fonetik modern menetapkan bahwa bunyi ['] adalah bunyi vokal panjang bersuara, yang dalam pengucapannya udara tidak menemui hambatan dalam alurnya, baik total maupun sebagian. Maka, kurang tepat menjadikan ['] sebagai bunyi pangkal rongga tekak.

(2) Tengah rongga tekak titik

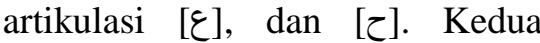
bunyi ini menurut fonetik modern adalah bunyi faringal, [ع] bersuara dan bunyi [ $\tau]$ tidak bersuara.

(3) Pangkal atas rongga tekak dan pangkal mulut titik artikulasi $[\dot{\zeta}]$, dan $[\dot{\xi}]$. Dalam fonetik modern kedua bunyi ini adalah velar (langit-langit lunak), bukan rongga tekak. Tammam Hasan (1989: 101) mengomentari: "Imam Sibawaih dan para pengikutnya menjadikan kedua bunyi ini bunyi faringal. Dalam hal ini, sikap yang bisa diikuti adalah: pertama, sikap menyalahkan pendapat Imam Sibawaih dan para pengikutnya jika persepsi mereka terhadap terminologi faring (الحلق) sama dengan persepsi kita saat ini. Kedua, tidak menyalahkan jika 
persepsi mereka dalam memahami terminologi faring lebih luas sehingga mencakup pangkal lidah dan langit-langit lunak".

(4) Di atas rongga tekak (anak tekak) dan pangkal lidah titik artikulasi [ق]. Dalam fonetik modern, bunyi [ق] adalah bunyi uvular (anak tekak). Redaksi Ibnu Jinni di atas tidak jauh dari pengertian ini. Meski tidak menyebut secara jelas anak tekak (اللَهَاة), tapi redaksi "di atas ujung rongga tekak dan pangkal lidah" sudah mewakilinya. (an-Nu'aimi, 1980: 305)

(5) Di atas titik artikulasi [ق] agak ke arah mulut adalah titik artikulasi bunyi [s]. Redaksi Ibnu Jinni ini agak rumit dipahami. Fonetik modern menyebut bunyi ini sebagai bunyi velum (langit-langit lunak). Redaksi Ibnu Jinni dapat didekatkan pengertiannya dengan fonetik modern saat dia membandingkan bunyi [s] dan [ق], bahwa [ك] lebih rendah dari [ق] dan agak maju ke depan. (anNu'aimi, 1980: 308)

(6) Antara tengah lidah dan tengah langit-langit atas (langit-langit keras/palatum) titik artikulasi bunyi [ج], [ش], dan [ي]. Fonetik modern menyebutkan tiga bunyi ini adalah bunyi palatal, yaitu yang keluar dari langit-langit keras.

(7) Di kanan kiri lidah dengan gigi geraham yang di dekatnya adalah titik artikulasi bunyi [ض], boleh ditekan dari sisi kanan, boleh juga dari sisi kiri. Demikian redaksi Ibnu Jinni tentang titik artikulasi [ض]. An-Nu'aimi (1980: 308) mengomentari, bahwa deskripsi Ibnu Jinni ini cukup detil. Dan ini harus diterima. Sebab, pengucapan [ض] secara benar sekarang ini sudah tidak ada, yakni bergeser menjadi bunyi lain seperti bunyi [ظ] di sebagian tempat, bunyi [د] tebal, dan bunyi [b] dalam dialek Maroko.

(8) Di tengah lidah sampai ujung lidah, langit-langit atas (gusi) tepat di atas gigi depan, gigi taring, dan geraham adalah titik artikulasi bunyi [J]. Deskripsi ini sama dengan deskripsi fonetik modern. Abduttawwab (1997: 47-48) menjelaskan, bunyi [J] diucapkan dengan ujung lidah menyentuh gusi, langit-langit lunak terangkat dan menutup alur udara ke hidung, dan udara lewat diantara sisi lidah dan gigi geraham. Udara tidak mampu melewati tengah mulut karena terhalang oleh ujung lidah yang menyentuh gusi. Karena itu, bunyi ini disebut lateral.

(9) Antara ujung lidah dan gusi titik artikulasi bunyi [ن]. Penjelasan ini sama dengan hasil penelitian fonetik modern yang mengklasifikasikan [ن] sebagai bunyi alvelor, yakni yang berasal dari gusi / alveolum. (Abduttawwab, 1997: 47)

(10) Di titik artikulasi bunyi [ن] hanya saja dengan sedikit punggung lidah karena condong ke bunyi [J] adalah titik artikulasi bunyi [J]. Bunyi ini juga termasuk bunyi alvelor dalam kajian fonetik modern.

(11) Antara ujung lidah dan akar gigi depan titik artikulasi bunyi [b], [د], dan [ت]. Tiga bunyi ini dalam fonetik modern termasuk bunyi dentialveolar, yakni yang berasal dari gigi dan gusi. Redaksi Ibnu Jinni di atas sama dengan fonetik modern. Akar gigi depan artinya gigi dan gusi. Ketiga bunyi ini sama titik artikulasinya, hanya saja [ت] tak bersuara, [د] bersuara, dan 
[b] bersuara juga velar. (anNu'aimi, 1980: 309)

(12) Antara ujung lidah dan gigi depan titik artikulasi bunyi [ص], [j], [w]. Dalam fonetik modern ketiga bunyi ini termasuk bunyi dentialveolar. Perbedaan antara ketiga bunyi itu adalah [j] bersuara, [w] tidak bersuara, dan [ص] tidak bersuara dan velar. (1980: 310)

(13) Antara ujung lidah dan ujung gigi depan titik artikulasi bunyi [ظ], [j], dan [ث]. Ketiga bunyi ini diklasifikasikan sebagai bunyi dental oleh fonologi modern. Perbedaan ketiganya adalah [j] bersuara, [ث] tidak bersuara, dan [ظ] bersuara dan velar. (1980:310)

(14) Antara bibir bawah dalam dan gigi atas depan titik artikulasi [ف]. Fonetik modern menyebutnya labio dental.

(15) Antara kedua bibir titik artikulasi bunyi [ب], [?], dan [g]. Fonetik modern menyebutnya bilabial. Bunyi [9] di atas bukan bagian bunyi vokal, melainkan semi vokal seperti dalam kata (وَاحد). Perbedaan keduanya tipis. Posisi pangkal lidah lebih terangkat ke langit-langit lunak dalam semivokal daripada vokal. (Abduttawwab, 1997: 93)

(16) Rongga hidung adalah titik artikulasi bunyi [ن] yang samar. Maksudnya adalah bunyi [ن] yang terdengar samar (ikhfä'), bukan yang mendengung (idghām) atau jelas (idzhār). Bunyi ini muncul jika ada huruf nun bersukun dan diikuti oleh salah satu dari 15 huruf, baik dalam satu kata atau dua kata. Kelimabelas huruf itu

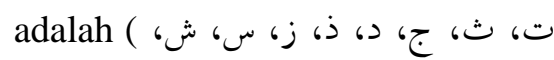
ك، Jinni menambahkan: "Bukti jika [ن] samar berasal dari rongga hidung adalah apabila engkau menutup lubang hidung kemudian engkau mengucapkan bunyi tersebut niscaya bunyi itu akan rusak. Sedangkan [ن] yang berharakat adalah termasuk bunyi mulut dengan disertai dengungan dari rongga hidung."

Tammam Hassan (1989: 106107) membagi bunyi [ن] ini menjadi beberapa bagian:

1) Nasal labiodental jika [ن] bersukun dan diikuti oleh [فنيْع : seperti

2) Nasal dental jika [ن] bersukun dan diikuti oleh

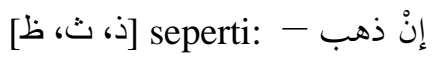

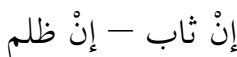

3) Nasal dentialveolar jika [ن] bersukun dan diikuti oleh [د، seperti: - إنْ دأب - إنْ تاب إناب إنْ طلب - إنْ زرع - إنْ إبْ صلح - إنْ سكت

4) Nasal alvelor jika [ن] berharakat atau bersukun dan tidak diikuti oleh huruf lain seperti: أنَا - نَفَ - أمانْ

5) Nasal palatal jika [ن] bersukun dan diikuti oleh

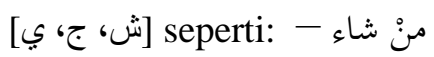
منْ جاء - منْ يكن 
6) Nasal velar jika [ن] bersukun dan diikuti oleh [ك] seperti: إنْ كان

7) Nasal uvular jika [ن] bersukun dan diikuti oleh [ق] seperti: إنْ قال

\section{b. Bunyi vokal}

Bunyi vokal adalah bunyi yang saat mengucapkannya udara tidak mengalami hambatan sama sekali dalam alurnya. Sedangkan bunyi konsonan adalah bunyi yang udara mengalami hambatan, baik total maupun sebagian, di beberapa titik artikulasinya. Dalam bahasa Arab, bunyi vokal disebut dengan istilah harakat dan huruf mad.

Ibnu Jinni mengkaji bunyi ini dalam bukunya Sirru Shinā'atilI'rāb. Dia menjelaskan (1993:17): "Ketahuilah, bahwa harakat adalah setengah dari huruf mad yaitu alif, ya', wau. Sebagaimana huruf mad ada tiga, begitu juga harakat, yaitu fatah, kasrah, dan dammah. Fatah adalah setengah dari alif, kasrah adalah setengah dari ya, dan dammah adalah setengah dari wau. Para ahli ilmu nahwu menyebut fatah dengan alif kecil, kasrah dengan ya kecil, dan dammah dengan wau kecil."

Pernyataan Ibnu Jinni ini sangat sesuai dengan apa yang disepakati oleh para ahli fonetik Arab modern. Mereka mengatakan, bahwa perbedaan antara fatah dengan alif hanya dalam panjang bunyi. Demikian juga, antara kasrah dengan ya, dammah dengan wau. Alif juga bisa disebut dengan fatah panjang, ya dengan kasrah panjang, dan wau dengan dammah panjang. (Anis, tt: 39-40).

Dari pernyataan Ibnu Jinni di atas dapat disimpulkan juga bahwa bunyi vokal yang diakui oleh ahli bahasa Arab ada tiga, terlepas dari panjang dan pendeknya. Yaitu: fatah, kasrah, dan dammah.

Selanjutnya, Ibnu Jinni menjelaskan argumen-argumen atas pernyataannya bahwa harakat adalah setengah dari huruf mad. Ibnu Jinni menegaskan (1993:18): "Jika Anda membaca panjang salah satu harakat, maka akan muncul, dalam tulisan, huruf yang harakat tersebut adalah setengahnya. Jika dibaca panjang fatah [ع] dalam kata عَ maka akan tertulis عَامَر, jika dibaca panjang kasrah [ع] dalam kata عَبَ maka akan tertulis عِينَب, dan jika dibaca panjang dammah [ع] dalam kata عُوَمَ maka akan tertulis. Jika memang harakat bukan setengah dari huruf mad, tentu huruf itu tidak muncul menyesuaikan harakat."

Pemanjangan harakat atau yang dikenal dengan istilah $i s y b \bar{a}$, lazim dilakukan oleh penyair Arab untuk menyelaraskan bait dengan wazan syair atau irama. Hal itu tidak hanya dilakukan di akhir bait (baik akhir setengah baris pertama atau kedua), melainkan juga di tengah-tengahnya, seperti:

$$
\begin{aligned}
& \text { وَأَنْتَ مِنَ الْفَوَائلِل حِينَ تُرْمَى }
\end{aligned}
$$

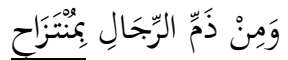

Maksudnya adalah بِ harakat fatah [j] dibaca panjang sehingga muncul [']. Demikian juga dengan harakat yang lain. (an-Nu'aimi, 1980: 326)

Argumen lain menurut Ibnu Jinni adalah semua abjad Arab, selain tiga abjad yang menjadi vokal panjang, dimungkinkan disertai harakat apapun tanpa ada kendala pelafalan atau tidak enak didengar, baik dalam keadaan sukun seperti [لَّم، سِلْم، : dalam سُلْم 
dalam سِعَاد، سَعِيد، سُعُوِد "Alif tidak

dapat disertai harakat kasrah atau dammah. Ya' bersukun dapat disertai dammah, juga wau bersukun dapat disertai kasrah, tetapi akan terasa berat atau dipaksakan." (1993:18-19)

Ibnu Jinni memberikan contoh kata Kedua kata ini sulit diucapkan. orang Arab mengganti [و] dengan [ي] menjadi قِيَل، طِيل Kata yang lain adalah

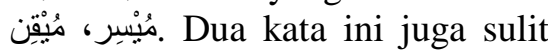
diulafalkan oleh orang Arab. Mereka mengganti [ي]dengan [و] menjadi مُؤسر، مُوْقِقِ Kemudian beliau menyimpulkan: "Bunyi [g] dan [ي] yang bersukun di atas mengalami perubahan karena saat Anda melafalkan kasrah Anda berarti melafalkan setengah dari bunyi [ي], dan Anda akan melafalkannya dengan sempurna. Tetapi, saat Anda melafalkan [g] setelah kasrah Anda telah merusaknya, karena tidak ada kesesuaian di antara keduanya. Demikian juga, saat Anda melafalkan dammah Anda telah melafalkan setengah dari [g]. Saat Anda melafalkan [ي setelah dammah Anda telah melafalkan bunyi yang tidak dikehendaki karena tidak ada kesesuaian di antara keduanya." (1993:19)

Argumen lain yang juga disampaikan oleh Ibnu Jinni adalah orang Arab memberikan perlakuan yang sama antara harakat dan huruf mad. Contoh memperlakukan huruf mad sama seperti harakat adalah لمَ لَغنزُ mad dalam keadaan i'rab jazm. Perlakuan ini sama seperti menghilangkan harakat dalam keadaan i'rab jazm dalam contoh . لم يقمْ، لم يقعذ Sedang contoh memperlakukan harakat sama seperti huruf mad adalah kata Kata yang menjadi nama orang perempuan ini bisa dibaca tanwin (munsharif) karena huruf keduanya (tengah) bersukun. Tetapi jika huruf keduanya berharakat maka tidak bisa menerima tanwin (ghairu munsharif). Hal ini sekan-akan sama dengan kata زَيَنَّنَ dan. Kedua kata ini tidak bisa dibaca tanwin karena terdiri dari empat huruf. Ibnu Jinni menyimpulkan, di sini harakat diperlakukan sama seperti huruf mad (1993:26).

Ibnu Jinni memandang harakat adalah huruf yang tidak sempurna. Dinamai harakat (gerak) karena menyimpan makna menggerakkan huruf yang disertainya, kemudian menariknya kepada huruf yang harakat itu adalah setengah dari huruf tersebut. Fatah menarik huruf yang disertainya kepada alif, kasrah kepada ya, dan dammah kepada wau. Harakat-harakat itu akan menjadi alif, ya, dan wau jika disempurnakan (dipanjangkan) pelafalannya. (1993:25-26)

Jika huruf mad itu adalah kepanjangan dari harakat, persoalannya adalah apakah harakat itu ada sebelum huruf $\mathrm{mad}$ ataukah tidak ada? Dengan kata lain, kata قال، يكون، misalnya, sebelum huruf mad harakat dianggap ada atau tidak ada?

Ibnu Jinni (1993:18) menyatakan bahwa jika harakat dipanjangkan maka akan muncul huruf yang harakat itu setengah dari huruf tersebut. Pernyataan Ibnu Jinni ini menjelaskan bahwa ada harakat sebelum huruf $\mathrm{mad}$, dan harakat itu sesuai dengan huruf mad tersebut. Ibnu Jinni juga berkeyakinan bahwa huruf konsonan pasti berharakat atau 
bersukun. Dan huruf konsonan, yang sebelum huruf $\mathrm{mad}$, berharakat sesuai dengan huruf mad tersebut. Dengan demikian, ada fatah sebelum alif dalam قَّقال dammah sebelum wau dalam يُكُن dan kasrah sebelum ya dalam بِيع

Pendapat ini juga menjadi pendapat ahli ilmu nahwu klasik yang lain. Mereka membagi abjad Arab adakalanya berharakat dan bersukun. Huruf-huruf mad itu tidak berharakat. Maka huruf sebelumnya harus berharakat agar tidak terjadi pertemuan dua huruf yang bersukun. Jadi, sebelum alif ada fatah, sebelum ya ada kasrah, dan sebelum wau ada dammah. (an-Nu'aimi, 1980:330)

Pendapat ini berbeda dengan sikap ahli fonetik Arab modern. Mereka berpandangan, tidak ada harakat sebelum huruf mad karena hakikat keduanya adalah satu, yaitu bunyi vokal. Maka huruf mad tidak dahului oleh harakat: alif tidak didahului fatah, ya' tidak didahului kasrah, dan wau tidak didahului dammah. Ibrahim Anis (tt: 24) mengatakan: "Ahli fonologi Arab klasik telah jauh dari kebenaran karena berpendapat terdapat harakat sebelum huruf mad."

Sikap Ibrahim Anis yang menyalahkan pandangan ahli fonologi klasik memiliki alasan yang kuat. Sejatinya di sana hanya ada satu bunyi vokal yaitu huruf mad saja. Akan tetapi, pandangan ahli fonetik klasik didasarkan atas sebuah teori yang disepakati para ahli saat itu. Teori ini adalah bahwa setiap huruf dalam sistem tulis bahasa Arab adakalanya berharakat atau bersukun. Sehingga, ada harakat yang melekat sebelum huruf mad. Ahli fonetik klasik belum memiliki persepsi seperti ahli fonetik modern. Hal ini tentunya bisa dimaklumi.

Selain tiga bunyi vokal di atas Ibnu Jinni juga menyebut bunyi vokal lain. Bunyi ini disebutnya sebagai vokal paduan. Ibnu Jinni mengatakan dalam al-Khashäish (2000, juz 3:120): “(Harakat) yang banyak dikenal orang Arab ada tiga, yaitu fatah, kasrah, dan dammah. Sebenarnya jumlahnya ada enam. Ada satu harakat paduan diantara dua harakat. Antara fatah dan kasrah ada fatah imâlah (condong ke kasrah), demikian juga antara alif dan ya ada alif imâlah, seperti dalam kata عَالم, Antara dalam kata fatah dan dammah terdapat fatah dan alif tafkhîm seperti fatah lam pada الحياة dan antara kasrah dan dammah terdapat kasrah dan ya' isymâm (condong ke dammah) seperti kasrah dalam ( )

Dalam pernyataannya tersebut, Ibnu Jinni menyebut ada 3 vokal paduan:

1. Fatah imâlah, yaitu fatah yang condong ke kasrah. Jika vokal ini dibaca panjang disebut alif imâlah. Keduanya adalah satu jenis, hanya berbeda dalam panjang dan pendeknya saja. Bunyi vokal ini dapat dilambangkan dengan / / / jika imâlah-nya ringan, atau dilambangkan dengan /e/ jika imâlah-nya berat. (Anis, tt: 34)

2. Fatah tafkhîm, yaitu fatah yang condong ke dammah. Jika dibaca panjang disebut alif tafkhîm. Bunyi ini bisa dilambangkan dengan /o/. (anNu'aimi, 1980: 332) Contohnya adalah kata الصلاة، الحياة.

3. Kasrah isymâm, yaitu kasrah yang condong ke dammah. Jika dibaca panjang disebut 
ya' isymām. Bunyi ini bisa dilambangkan dengan /ui/. (anNu'aimi, 1980: 332). Contohnya adalah kata بيع، قيل

\section{c. Bunyi konsonan}

Ibnu Jinni menjelaskan bunyi konsonan satu persatu dalam bukunya Sirru Shināati 'l-I'rāa' dalam satu bab, dari Bābu ' $l$ Hamzah, Bābu ' $l-B \bar{a}$ ', sampai $B \bar{a} b u$ ' $l-Y \bar{a}$ '. Di awal setiap bab, Ibnu Jinni menjelaskan apakah bunyi itu bersuara (majhûr) atau tidak bersuara (mahmûs), kemudian menjelaskan perubahanperubahan bunyi itu dalam sebuah kata.

Ibnu Jinni menjelaskan maksud istilah bunyi bersuara. Dia mengatakan (1993: 60): "Bunyi yang bertekan pada tempatnya secara kuat, dan mencegah udara mengalir bersamanya, sampai berakhir kebertekanan tersebut dan udara dapat mengalir". Sedangkan bunyi tidak bersuara didefinisikan "Bunyi yang lemah bertumpu pada tempatnya sehingga udara tetap dapat mengalir". Yang dimaksud "tempat" dalam pernyataan Ibnu Jinni di atas bukanlah pita suara sebagaimana ahli fonetik modern memandang bunyi bersuara dan tidak bersuara. Ibnu Jinni dipastikan masih belum memahami pita suara karena keterbatasan teknologi saat itu. Maksud dari "tempat" itu adalah alur udara yang di dalamnya terdapat titik artikulasi. Hal ini diperjelas dengan penjelasan Ibnu Jinni saat menjelaskan bunyi [ ?]. Ibnu Jinni menyebut kedua bunyi itu bertekan pada mulut dan rongga hidung sehingga keduanya sengau (1993: 60). Dalam proses pembentukan kedua bunyi itu, udara melewati rongga hidung karena rongga mulut tertutup.
Kebertekanan bunyi bersuara pada alur udara secara kuat menjadikan bunyi ini lebih keras dari bunyi tidak bersuara. Hal inilah yang dipahami oleh Ibnu Jinni terkait istilah majhûr (yang dikeraskan). Udara pun tidak mengalir saat bunyi bertekan pada alur udara. Udara itu baru mengalir setelah selesai proses bertekan tersebut. Tampaknya, Ibnu Jinni memahami istilah majhûr ini dengan adanya stressing yang menjadikan bunyi lebih terdengar keras. Hal ini berbeda dengan ahli fonetik modern. Mereka memandang bunyi bersuara dikarenakan pita suara bergetar.

Menurut Ibnu Jinni bunyi tidak bersuara itu ada sepuluh. Selain itu maka masuk bunyi bersuara. Kesepuluh bunyi itu هـ، ح، خ، ك، ش، ص، ت، س، ] ف] yang tergabung dalam

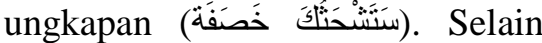
kesepuluh bunyi ini yang bersuara أ، ب، ج، د، ذ، ر، ز، ض، ض، ط، ظ، [ ]

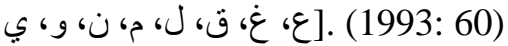

Bunyi konsonan dikenal juga dengan istilah kontoid. Artinya, mengalami hambatan saat artikulasi. Hal ini berbeda dengan bunyi vokal atau vokoid. Hambatan itu terkadang total sehingga disebut plosif atau letupan, dalam bahasa Arab istilahnya adalah syiddah. Terkadang juga sebagian sehingga disebut frikatif atau geseran, dalam bahasa Arab istilahnya adalah rakhâwah.

Terkait hal ini Ibnu Jinni membagi bunyi menjadi dua: syiddah dan rakhâwah. Dia menjelaskan (1993: 61), pengertian syiddah adalah bunyi yang udara tidak bisa mengalir bersamanya seperti bunyi [b] dan [ق] dalam (الحقّ، الثطّ). Sedangkan rakhâwah adalah bunyi yang udara 
bisa mengalir bersamanya seperti bunyi [ح] dan [س] dalam ( المسّ، (الشخّ). Ibnu Jinni juga menyebut bunyi-bunyi yang tidak letupan dan tidak geseran, yakni antara keduanya. Hanya saja, dia tidak menjelaskannya lebih lanjut.

Penjelasan Ibnu Jinni ini sudah sesuai dengan pendapat ahli fonetik modern yang menyatakan bahwa pada bunyi letupan udara terhalang di belakang dua titik artikulasi yang menutup rapat. Saat kedua titik artikulasi itu dilepaskan secara tiba-tiba maka muncullah bunyi letupan itu. Sedangkan dalam bunyi frikatif udara masih tetap mengalir dan menggeser dua titik artikulasi yang menyempit.

Menurut Ibnu Jinni (1993: 61) bunyi letupan dalam bahasa Arab adalah [أ، ق، ك، ج، ط، د، ت، ب yang

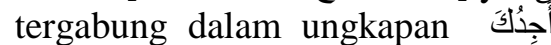
ط طَبَقَتَ . Dan bunyi diantara letupan dan geseran ada delapan juga yaitu
[ا، ع، ي، ل، ن، ر، م، و bunyi geseran adalah selain keenambelas bunyi tersebut, yaitu ث، ح، خ، ذ، ز، س، ش، ص، ض، ظ، غ، ] هـ فـ

Ibnu Jinni menyebut bunyi [ل] bunyi muncharif, yakni bunyi yang lidah membelokkan udara, kedua sisi ujung lidah renggang tidak menghalangi udara, sehingga udara melewati sisi kanan dan kiri lidah, juga di diantara kedua sisi ujung lidah yang renggang. (1993: 63) Penjelasan ini sudah sesuai dengan fonetik modern yang menyebut [J] bunyi lateral.

Ibnu Jinni menyebut bunyi [ $\mathrm{J}]$ bunyi mukarrar. Dia mengatakan (1993: 63): "Jika engkau berhenti pada bunyi [J] engkau mendapati ujung lidah bergetar berulang kali”.

Berikut diagram pembagian bunyi bahasa Arab berdasarkan titik artikulasi dan bentuk bunyi menurut ahli fonetik Arab modern (Abduttawwab, 1997: 61).

\begin{tabular}{|c|c|c|c|c|c|c|c|c|c|c|c|c|c|}
\hline \multirow{4}{*}{$\begin{array}{l}\text { Titik } \\
\text { artikulasi }\end{array}$} & \multicolumn{13}{|c|}{ Bentuk bunyi } \\
\hline & \multicolumn{4}{|c|}{ Plosif } & \multicolumn{4}{|c|}{ Frikatif } & \multirow{3}{*}{\begin{tabular}{|c|} 
afrikatif \\
brsuara
\end{tabular}} & \multirow{2}{*}{\multicolumn{4}{|c|}{$\begin{array}{c}\text { Tengah-tengah } \\
\text { Bersuara }\end{array}$}} \\
\hline & \multicolumn{2}{|c|}{ Bersuara } & \multicolumn{2}{|c|}{$\begin{array}{c}\mathrm{T} \\
\text { bersuara }\end{array}$} & \multicolumn{2}{|c|}{ bersuara } & \multicolumn{2}{|c|}{$\begin{array}{c}\mathrm{T} \\
\text { bersuara }\end{array}$} & & & & & \\
\hline & tps & $\begin{array}{c}\mathrm{Tb} \\
1\end{array}$ & tps & tbl & $\begin{array}{r}\mathrm{T}_{1} \\
\mathrm{~s}\end{array}$ & $\mathrm{tb}$ & tps & $\mathrm{tbl}$ & & $\begin{array}{c}\text { 1atera } \\
1\end{array}$ & nasal & getar & semivkl \\
\hline Bilabial & ب ب & & & & & & & & & & 5 & & و \\
\hline Labiodental & & & & & & & ف & & & & & & \\
\hline Dental & & & & & $\vdots$ & E & 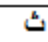 & & & & & & \\
\hline $\begin{array}{l}\text { Dentialveol } \\
\text { ar }\end{array}$ & 2 & ض & $ت$ & $b$ & 3 & & س & ט & & & & & \\
\hline Alveolar & & & & & & & & & & $J$ & $\dot{0}$ & J & \\
\hline Palatal & & & & & & & ش ش م & & ₹ & & & & ي ي \\
\hline Velar & & & s & & $\dot{\varepsilon}$ & & $\dot{\tau}$ & & & & & & \\
\hline Uvalar & & & ق & & & & & & & & & & \\
\hline Faringal & & & & & $\varepsilon$ & & $\tau$ & & & & & & \\
\hline Laringal & & & 5 & & & & هـ & & & & & & \\
\hline
\end{tabular}


Berikut tabel pembagian bunyi bahasa Arab yang disarikan dari pendapat Ibnu Jinni:

\begin{tabular}{|c|c|c|c|c|c|c|c|c|c|c|c|}
\hline \multirow[t]{4}{*}{ Titik artikulasi } & \multicolumn{11}{|c|}{ Bentuk bunyi } \\
\hline & \multicolumn{4}{|c|}{ Letupan } & \multicolumn{4}{|c|}{ Geseran } & \multicolumn{3}{|c|}{ Tengah-tengah } \\
\hline & \multicolumn{2}{|c|}{ Bersuara } & \multicolumn{2}{|c|}{ T bersuara } & \multicolumn{2}{|c|}{ Brsuara } & \multicolumn{2}{|c|}{ T bersuara } & \multicolumn{2}{|c|}{ Bersuara } & \multirow[b]{2}{*}{$\begin{array}{c}\text { mukarra } \\
\kappa\end{array}$} \\
\hline & tps & tbl & tps & tbl & tps & tbl & tps & tbl & munharif & anfiy & \\
\hline Dua bibir & ب ب & & & & & & & & & 5 & \\
\hline $\begin{array}{l}\text { Bibir bawah\& } \\
\text { gigi atas }\end{array}$ & & & & & & & قـ & & & & \\
\hline $\begin{array}{l}\text { Ujunglidah \& } \\
\text { ujung gigi depan }\end{array}$ & & & & & $i$ & b & ث & & & & \\
\hline $\begin{array}{l}\text { Ujunglidah \& } \\
\text { gigi depan }\end{array}$ & & & & & $j$ & & w & صن & & & \\
\hline $\begin{array}{l}\text { Ujunglidah \& } \\
\text { akar gigi depan }\end{array}$ & 2 & $b$ & $=$ & & & & & & & & \\
\hline $\begin{array}{l}\text { Ujung punggung } \\
\text { lidah \& gusi. } \\
\text { bag. atas }\end{array}$ & & & & & & & & & & & J \\
\hline $\begin{array}{l}\text { Ujunglidah \& } \\
\text { gusi bag. bawah }\end{array}$ & & & & & & & & & & i & \\
\hline $\begin{array}{l}\text { Tengah-ujumg } \\
\text { lidah \& gusi }\end{array}$ & & & & & & & & & J & & \\
\hline $\begin{array}{l}\text { Kanan-kirilidah } \\
\text { \& gigi geraham }\end{array}$ & & & & & & ضن & & & & & \\
\hline $\begin{array}{l}\text { Tengah lidah \& } \\
\text { langit-langit } \\
\text { keras. }\end{array}$ & $\varepsilon$ & & & & & & شن & & & & \\
\hline $\begin{array}{l}\text { Di atas anak } \\
\text { tekak }\end{array}$ & & & 9 & & & & & & & & \\
\hline $\begin{array}{l}\text { Anak tekak \& } \\
\text { pangkal lidah }\end{array}$ & ق & & & & & & & & & & \\
\hline $\begin{array}{l}\text { Rongga tekak } \\
\text { atas \& pangkal } \\
\text { mulut }\end{array}$ & & & & & $\bar{\varepsilon}$ & & $\bar{\tau}$ & & & & \\
\hline $\begin{array}{l}\text { Rongga tekak } \\
\text { tengah }\end{array}$ & & & & & $\varepsilon$ & & $\tau$ & & & & \\
\hline $\begin{array}{l}\text { Rongga tekak } \\
\text { pangkal }\end{array}$ & 5 & & & & & & هـ & & & & \\
\hline
\end{tabular}

\section{Kesimpulan}

Ibnu Jinni telah memberikan konstribusi besar dalam pengembangan kajian fonetik bahasa Arab. Dia adalah orang pertama yang menuliskan materimateri pembahasan fonetik Arab dalam satu buku khusus yang dia beri nama Sirru Shinâ'atil-I'râb. Dalam karyanya ini, Ibnu Jinni membahas titik artikulasi, bunyi vokal, bunyi konsonan dan deskripsi masing-masing.

Pembahasan bunyi vokal adalah salah satu konstribusi penting dari Ibnu
Jinni. Dia menjelaskan definisinya, macam-macamnya, kedudukan vokal dalam tata tulis bahasa Arab dimana pembahasan-pembahasan itu tidak ditemukan, dengan kedalaman yang sama, dalam karya-karya ulama pada masa itu. 


\section{Daftar Pustaka}

Abduttawwab, Ramadan. 1997. AlMadkhal ilâ 'Ilmil-Lughati. Kairo: Maktabah al-Khanji.

Al-Anbari, Ibnu. 1985. Nuzhatu alAlibbâ'i fì Thabaqâti al-Udabâ'i. Yordania: Maktabah Al-Manar.

Anis, Ibrahim. TT. Al-Ashwât alLughawiyyah. Kairo: Maktabah Anglo Mashriyyah.

An-Nu'aimi, Husam Sa'id. 1990. Ibnu Jinni 'Alimul-'Arabiyyah. Baghdad: Kementerian Budaya dan Informasi.

1980. Ad-DirâsâtulLahjiyyah wash-Shautiyyah 'Inda Ibni Jinni. Baghdad: Kementerian Kebudayaan dan Penerangan Republik Irak.

As-Samirra'i, Fadhil Shaleh. 1969. Ibnu Jinniy an-Nahwiy. Baghdad: Dar anNadzîr.
Dlaif, Syauqi. 1992. Al-MadârisunNahwiyyah. Kairo: Darul Ma'arif.

Jinni, Ibnu. Editor Muhammad Ali anNajjar. 2000. Al-Khashâish. Kairo: Darul Kutub al-Mishriyyah.

Editor Hasan Hindawi. 1993. Sirru Shinâ'atil-I'râb. Damaskus: Darul Qalam.

Hassan, Tammam. 1989. Manâhijul-Bahts fil-Lughati. Hilmiyet Zaitoun Kairo: Maktabah an-Nasr.

Khallikan, Ibnu. 1994. Wafyâtul-A'yân wa Anbâ'u Abnâi az-Zamân. Beirut: Dar ash-Shadir.

Umar, Ahmad Mukhtar. 1988. Al-BahtsulLughawiyyi 'Indal-'Arab. Kairo: 'Alamul Kutub.

Shalih, Shubhi. 2004. Dirâsâtu fî FiqhilLughah. Beirut: Darul Ilmi lilMalâyîn. 